\title{
Changes in body height among selected ethnic groups
}

\author{
Arie Laor, Daniel S Seidman, Yehuda L Danon
}

\begin{abstract}
Study objective-The aim was to assess the effects of genetic factors and environmental influences on adolescence body height.

Design-The study was a retrospective survey of mean standing height collected from computerised medical draft records of 17-18 year old adolescents, born between 1950 and 1971.

Setting-All the studied population is resident of the state of Israel.

Participants-About half a million records of recruits were examined. The sex distribution was: $61 \%$ male, $39 \%$ female. Ethnic distribution of the studied population was according to the countries of origin: Poland $\mathbf{7 \cdot 8 \%}$, Romania $\mathbf{2 2 . 0 \%}$, Yemen $11 \cdot 4 \%$, Iraq $17 \cdot 5 \%$, Morocco $27 \cdot 4 \%$, and Israel $7 \cdot 8 \%$.

Measurements and main resultsMarked differences in standing height measures were found between the ethnic groups compared to the Israeli reference group. A linear increase of $1.1 \mathrm{~mm} /$ year for reference males and $0.8 \mathrm{~mm} /$ year for the female population was found over the 22 years of study period. Ethnic groups with lower mean height were found to have a significantly greater increase in height during the period studied.

Conclusions-Israel as an immigration country may serve as a model for the study of environmental and genetic factors. Under conditions found in Israel, body height continues to increase with year of birth, while significant differences in height between ethnic groups has diminished.
\end{abstract}

Body height among adults is determined by genetic factors and environmental influences during the years of growth. ${ }^{1-3}$ Differences in mean standing height found for various ethnic groups $^{4}$ may thus reflect socioeconomic and demographic inequalities among ethnic groups 56 rather than the effect of genetic variance.

The rich mixture of native born and immigrant groups of different ethnic origin makes Israel a convenient population laboratory for the study of genetic versus environmental effects. ${ }^{7}$ We took advantage of a national database of all Jewish children born in Israel between 1950 and 1971 to assess the changes over time in body height differences at 17-18 years of age between selected ethnic groups. The data provided by the unique Israeli Defence Force (IDF) database of conscripts allowed evaluation of body height in relation to year of birth, ethnic origin, country of birth, age at immigration to Israel, and sex.

\section{Methods}

The study population consisted of about half a million recruits born between 1950 and 1971 and aged 17-18 years at the time when they passed the medical draft examination. The present computerised database has previously been described in detail. ${ }^{8}$ The sex distribution was $61 \%$ males and $39 \%$ females, as orthodox Jewish females are not required to undergo draft examination. The ethnic groups were determined by the fathers' or grandfathers' (when the father was Israeli born) country of birth. Six ethnic groups comprising $70^{\circ}$ o of the entire draft population were analysed. These ethnic groups were chosen because they were large and homogeneous. Countries with substantial Jewish immigration over the last century, including the USA, Western Europe, Canada, Australia, and South America, were excluded. The ethnic distribution was: Poland $\left(7 \cdot 8^{\circ}{ }_{0}\right)$, Romania $(22.0 \%)$, Yemen and Aden $\left(11.4^{\circ}{ }_{0}\right)$, Iraq $(17 \cdot 5 \%)$, Morocco $\left(27 \cdot 4^{\circ}{ }_{0}\right)$, Israel $\left(7 \cdot 8^{\circ}{ }_{0}\right)$. Immigration according to the status of conscript was grouped in five categories: (a) born in Israel $(87.8 \%)$; (b) immigrated at age $0-2$ years $\left(2 \cdot 8^{\circ}{ }_{0}\right)$; (c) immigrated at 2-6 years $\left(4 \cdot 4^{\circ}{ }_{0}\right)$; (d) immigrated at $6-12$ years $\left(4 \cdot 0^{\circ}{ }_{\mathrm{o}}\right)$; (e) immigrated at age 12 years or older $\left(1 \cdot 1_{0}^{\circ}\right)$.

Standing height was measured using a fixed stadiometer. The subjects were told to take off their shoes and stand straight, so the heels, buttocks, and shoulders were in contact with the vertical backboard of the stadiometer and the head aligned such that the Frankfort plane was parallel to the floor. The command "take a deep breath and stand tall" was given to encourage the subject to straighten the spine. Height was measured to nearest centimetre.

\section{Results}

The proportion of recruits by ethnic origin over time is presented in the table.

A separate general linear model was fitted for each sex. The reference group included all subjects born in Israel during 1950 to parents of Israeli origin. The overall mean (SEM) body heights were $173.48(0.01) \mathrm{cm}$ for the males and $162 \cdot 80(0 \cdot 02) \mathrm{cm}$ for the females. The ethnic effect on height was similar for males and females. The Israeli ethnic groups served as a reference group. The Polish (males, $174.1 \mathrm{~cm}$ ) and Romanian (males, $174.0 \mathrm{~cm}$ ) groups were found to be the tallest and the Yemenite (males, $167.0 \mathrm{~cm}$ ) the 
Proportion of recruits by ethnic origin, sex, and year of birth

\begin{tabular}{|c|c|c|c|c|c|c|}
\hline \multirow[b]{2}{*}{ Birth year } & \multicolumn{6}{|l|}{ Origin } \\
\hline & $\begin{array}{c}\text { Israel } \\
(\%)\end{array}$ & $\begin{array}{l}\text { Morocco } \\
(\%)\end{array}$ & $\begin{array}{l}\text { Poland } \\
(\%)\end{array}$ & $\begin{array}{l}\text { Romania } \\
(0)\end{array}$ & $\begin{array}{l}\text { Yemen } \\
\text { and Aden } \\
(\%)\end{array}$ & $\begin{array}{c}\text { Iraq } \\
(\%)\end{array}$ \\
\hline $\begin{array}{l}1950 \text { to } 1954 \\
\text { Male } \\
\text { Female }\end{array}$ & $\begin{array}{l}7 \\
6\end{array}$ & $\begin{array}{l}25 \\
13\end{array}$ & $\begin{array}{l}25 \\
41\end{array}$ & $\begin{array}{l}14 \\
20\end{array}$ & $\begin{array}{r}13 \\
8\end{array}$ & $\begin{array}{l}16 \\
12\end{array}$ \\
\hline $\begin{array}{l}1955 \text { to } 1959 \\
\text { Male } \\
\text { Female }\end{array}$ & $\begin{array}{l}8 \\
7\end{array}$ & $\begin{array}{l}32 \\
24\end{array}$ & $\begin{array}{l}18 \\
26\end{array}$ & $\begin{array}{l}13 \\
17\end{array}$ & $\begin{array}{r}12 \\
9\end{array}$ & $\begin{array}{l}17 \\
17\end{array}$ \\
\hline $\begin{array}{l}1960 \text { to } 1964 \\
\text { Male } \\
\text { Female }\end{array}$ & $\begin{array}{r}10 \\
8\end{array}$ & $\begin{array}{l}33 \\
29\end{array}$ & $\begin{array}{l}15 \\
20\end{array}$ & $\begin{array}{l}11 \\
14\end{array}$ & $\begin{array}{l}13 \\
10\end{array}$ & $\begin{array}{l}18 \\
19\end{array}$ \\
\hline $\begin{array}{l}1965 \text { to } 1970 \\
\text { Male } \\
\text { Female }\end{array}$ & $\begin{array}{l}13 \\
10\end{array}$ & $\begin{array}{l}31 \\
29\end{array}$ & $\begin{array}{l}16 \\
19\end{array}$ & $\begin{array}{l}11 \\
14\end{array}$ & $\begin{array}{r}12 \\
9\end{array}$ & $\begin{array}{l}17 \\
19\end{array}$ \\
\hline
\end{tabular}

shortest in 1950. The age at time of immigration had a negative influence on height; that is, the older the immigrant was on arrival to Israel, the shorter his height during the draft examination.

A linear increase in mean height of $1.1 \mathrm{~mm} /$ year was observed for the reference males and 0.8 $\mathrm{mm} /$ year for the females over the 22 year study period (figure). This trend was found for all ethnic groups. However, ethnic groups with a lower mean height were found to have a significantly greater increase in height during the time period studied. After controlling for the effect of year of birth, both ethnic group and age at immigration remained significantly $(p<0.0001)$ associated with body height.

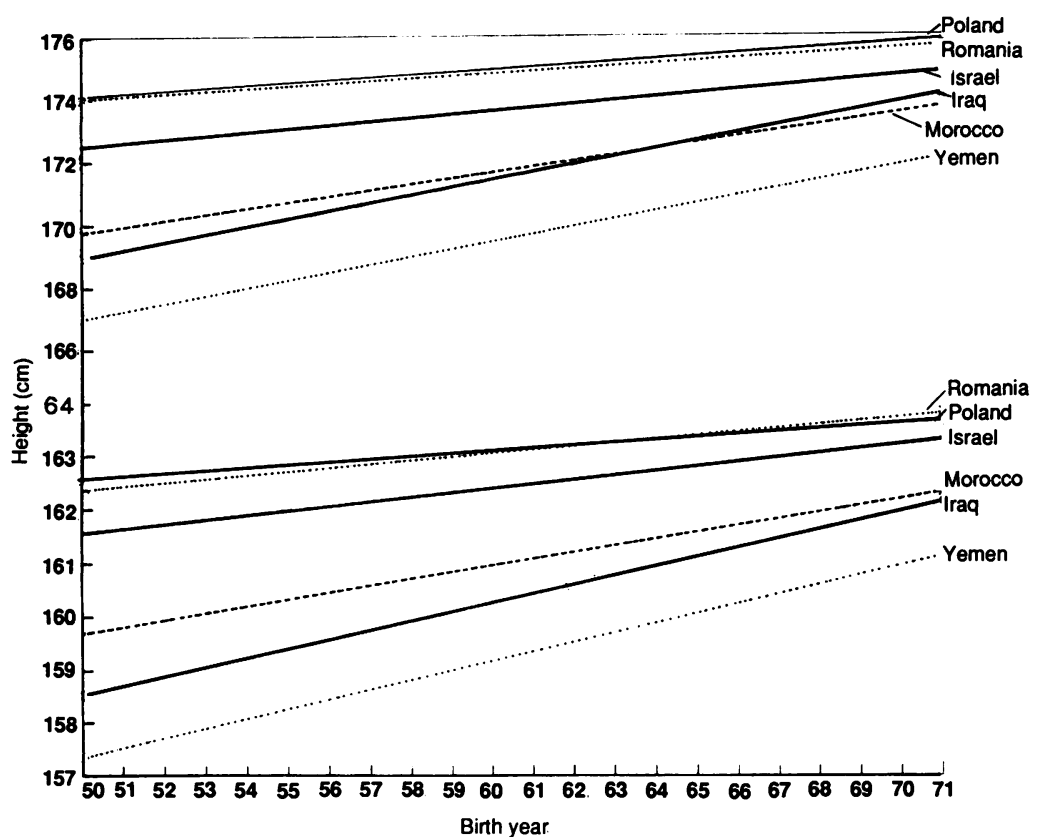

Adjusted height at 17 years of age by year of birth and ethnic origin (males-top; females-bottom).

\section{Discussion}

The population of Israel increased from 872700 in 1948 to 3095100 at the beginning of $1971 .^{9}$ The population growth was largely $(59.6 \%)$ due to constant immigration from many countries. Since the majority of immigrant groups had lived in their country of origin for centuries, it is not surprising that Jewish communities differ in gene frequencies in various loci. ${ }^{10}$ Furthermore, Jews from European, Asian, and North African countries enjoyed very diverse socioeconomic and hygienic living conditions. ${ }^{7}$ From the regression line in the figure it can be noted that body height has continued to increase with year of birth, but the significant difference in adult height between ethnic groups has diminished. The fall in differences in height between ethnic groups is probably attributable to changing living conditions during childhood. This may partially be explained by the disappearance of social class differences among Jewish ethnic groups in Israel and change in standard of living. However, the significant influence of the age at the time of immigration on height at 17-18 years of age suggests that growth rate was higher in Israel. The melting pot effect of this immigration country provides a strong demonstration of the large contribution made by environmental conditions on final height attainment of various ethnic groups. Although the differences may never entirely disappear, as there is a significant genetic contribution to height, improvement of living conditions is likely to reduce most of variance.

This study was supported by the Doron Foundation.

1 Taasdale TW, Sorensen TIA, Owen DR. Fall in association of height with intelligence and educational level. $B M F$ 1989; 298: 1292-3.

2 Nystrom Peck AM, Vagero DH. Adult body height and chilhood socioeconomic group in the Swedish population. $₹$ Epidemiol Community Health 1987; 41 popula.

3 Walker M, Shaper AG, Wannamethee G. Height and social class in middle-aged British men. $\mathcal{f}$ Epidemiol Community Health 1988; 42: 299-303.

4 Spurgeon JH, Meredith HV, Onuoha GBI. Comparisons of body size and form among ethnic groups of United States college men. Growth 1986; 50: 250-8.

5 Ling SYK, King NM. Secular trends in stature and weight in southern Chinese children in Hong Kong. Ann Hum Biol 1987; 14: 187-90.

6 Whincup PH, Cook DG, Shaper AG. Social class and height. $B M F$ 1988; 297: 980-1.

7 Davias AM. Migrants and their children in Israel. Identification and change. Israel f Med Sci 1971; 7: 1342-7.

8 Kark JD, Kedem R, Revach M. Medical examination of Israeli 17 year olds before military service as a national resource for health information. Israel $\mathcal{F}$ Med Sci 1986; 22: 318-25.

9 Central Bureau of Statistics. Statistical abstract of Israel. Jerusalem: Israel Government Press 1978: 29.

10 Cohen T.Genetic markers in migrants to Israel. Israel f Med Sci 1971; 7: 1509-14. 